\title{
TAXATION OF STRIKE BENEFITS
}

$T_{\text {he recent case of Kaiser } v \text {. United States }}{ }^{1}$ represents the first judicial pronouncement on the taxability of strike benefits paid to a worker by a union. In that case, the Court of Appeals for the Seventh Circuit held that strike benefits paid to a Kohler worker, who was not a union member for a portion of the time during which he received the benefits, ${ }^{2}$ were gifts, expressly reversing the district court's view that the payments constituted taxable compensation. ${ }^{3}$ The Treasury has previously ruled that strike, ${ }^{4}$ lockout ${ }^{5}$ and unemployment ${ }^{6}$ benefits paid to workers by a union are taxable as income because of the compensatory element involved in such payments. Thus, the Kaiser decision expressly repudiates one of these rulings and at least raises questions as to the validity of the remaining two.

The district court, upholding the Treasury rulings, brought the strike payments within the broad language of section $6 \mathrm{I}$ (a) of the Internal Revenue Code, which includes within gross income "income from whatever soune derived." The court reasoned that the strike benefits did not come within the statutory exclusion for gifts ${ }^{8}$ because the payments were made pursuant to a provision in the union's constitution which required a worker to remain on strike to be eligible to receive

${ }_{2}^{262}$ F.2d ${ }_{367}$ (7th Cir. 1958), reversing 158 F. Supp. 865 (E.D. Wis. 1958). The district court decision is ably noted in 13 ARK. L. REv. 75 (1959).

${ }^{2}$ Taxpayer was an employee of the Kohler Company at Sheboygan, Wisconsin, when the strike, which was approved by the United Automobile, Aircraft, and Agricultural Implement Workers of America, began on April 5, 1954. He began receiving strike benefits on May 4th and continued to receive them throughout the rest of the taxable year. On August igth, he became a member of the union, but he did not pay any initiation fee or dues because he was on strike.

${ }_{15}{ }_{15}$ F. Supp. 865 (E.D. Wis. 1958).

- O.D. 522, 2 CUM. BulL. 73 (1920), made strike benefits paid by a union to its members includible in gross income. Rev. Rul. 1, 1957-1 CuM. BuLL. 15 has restated this ruling to include benefits given to nonmembers.

${ }^{5}$ Rev. Rul. 58-139, 1958 INT. REv. BuLL. No. 14, at 7.

${ }^{\circ}$ I.T. 1293, I-1 CUM. Bull. 63 (1922).

: The source of this section was INT. REv. CODE OF 1939, § 22 (a), which defined gross income as including "gains, profits, and income derived from ... . compensation for personal service, of whatever kind and in whatever form paid ... or gains or profits and income derived from any source whatever." The restatement of this definition in $\S 6 \mathrm{I}(\mathrm{a})$ of the 1954 Code has left its meaning substantially unchanged.

${ }^{8}$ INT. REv. CODE OF 1954, § $102(a)$, provides that "gross income does not include the value of property acquired by gift. . . ." 
payments, ${ }^{9}$ and because no payments were actually made to workers who were not on strike. The court of appeals, however, emphasized that need was the primary qualification for receipt of strike benefits, that the amount of the benefit was determined solely by reference to personal need rather than former earnings, ${ }^{10}$ and that the union had neither $a$. legal nor a moral obligation to make the payments. ${ }^{11}$

The decision in the instant case seems to be at odds with the presumed intent of Congress to tax all increments of economic benefit except those specifically excluded by statute. ${ }^{12}$ The Supreme Court, in accordance with this purpose to tax income comprehensively, has frequently held that the statutory concept of "income" should be broadly

${ }^{8}$ Article $16, \S 11$, of the International Union Constitution provided as follows: "All Local Unions shall pay to the International Union a per capita tax ... which shall be set aside in a special fund as the International Strike Fund, to be drawn upon exclusively for the purpose of aiding Local Unions engaged in authorized strikes and in cases of lockout, and for that purpose only, and then only upon a two-thirds vote of the International Executive Board.” 158 F. Supp. 865, 867 (E.D. Wis. 1958).

${ }^{10}$ Strikers, when making application for benefits, were required to answer a union questionnaire concerning their personal needs, marital status, and number of dependents. The amount of the benefits which were given to each striker was determined by reference to this questionnaire.

${ }^{11}$ The district court had concluded that dues paying members had a moral right, and perhaps even an enforceable right, to benefits if they were arbitrarily denied. This moral right was inferred from the fact that the strike was conducted with the approval of the International Executive Board, and from the fact that art. 12, $\S 15$, of the International Union Constitution made it "the duty of the Intermational Executive Board to render all financial assistance to the members on strike consistent with the resources and responsibilities of the International Union." 158 F. Supp. 865,867 (E.D. Wis. 1958).

${ }^{19}$ See Commissioner v. LoBue, 351 U.S. 243, 246 (1956); Commissioner v. Glenshaw Glass Co., 348 U.S. 426, 429-30 (1955). The Seventh Circuit Court of Appeals took exception with this presumed intent by citing the following instances where payments have not been taxed, even though not specifically excluded by statute: (1) retirement benefits under the Federal OId Age and Survivors' Insurance System, (2) damages for alienation of affection, (3) damages for breach of promise to marry, (4) awards under a wrongful death statute, (5) payments to war prisoners for mistreatment by their captors, (6) unemployment compensation benefits paid by a state, (7) public assistance relief payments, (8) food and medical supplies and other forms of subsistence given by the American Red Cross to disaster victims, and (9) rehabilitation payments to tornado victims given by a large corporate employer in a disaster area. 262 F.2d 368-69. The Treasury has previously distinguished these payments by saying, "The benefits in these cases were held not to constitute taxable income because it was believed that Congress intended that such benefits be not subject to the tax. However, there is no evidence that Congress intended to exclude strike benefits from income." Rev. Rul. 1, 1957-1 CUM. BuLl. 35, 16. 
construed. ${ }^{13}$ Similarly, the Supreme Court has construed statutory ex: clusions narrowly: ${ }^{14}$. Even if it be conceded that strike benefit payments are motivated in part by feelings of charity, it seems apparent that such payments include an attending element: of compenșation, in as much. as a. union benefits from a strike commensurately. with its ability to. persuade all of the workers in a plant to remain on strike. In such a close case, the judicially sanctioned policy of construing exclusions narrowly would seem to control and to dictate a finding that strike benefits are not gifts.

Even apart from considerations of statutory construction, the validity of the Kaiser decision is impaired by an objective view of economic realities. Both the Commissioner and the taxpayer agreed that payments were distributed only to striking workers. ${ }^{15}$ It is unlikely that the union would have made payments to nonunion strikers had it not expected to benefit by their continued participation in the strike. And the fact that the amounts paid were measured by need does not necessarily establish a charitable motive in making the payments. It would be at least as logical to attribute adversion to need to a basic desire to prevail in the strike, since a union must apportion benefits according to need if it hopes to dissuade workers from returning to their ald jobs or finding new ones. Under this rationalization, the payments do not fit the usual concept of a gift, which is commonly thought to be prompted by feelings of love or charity. ${ }^{16}$

Since the Kaiser case is the first decision dealing with the taxability of out-of-work payments by a union, the scope of the court's holding is a significant question. Conceivably, strike benefits might be paid to

\footnotetext{
${ }^{23}$ Commissioner v. Jacobson, 336 U.S. 28 (1949), is the leading case on this point. It was followed in Commissioner v. LoBue, 351 U.S. 243 (1956), and Commissioner v. Glenshaw Glass Co., 348 U.S. 426 (1955).

${ }^{14}$ Ibid.

${ }^{1 i}$ It was stipulated by the parties that, "The International Union grants strike benefits to non-members of the Union, who participate in the strike, if they do not have snfficient income to purchase food or to meet an emergency situation. The Union treats such non-members on the same basis as members of the Union, but non-members as well as members must be strikers before they may receive assistance from the Union." 262 F.2d 367, 371 (7th Cir. 1958) (Duffy, C.J., dissenting).

${ }^{16} \mathrm{~A}$ gift is "made with detached and disinterested generosity, and is basically giving something away for nothing." Commissioner v. LoBue, 351 U.S. 243, 246-47 (1956). A gift is "the receipt of financial advantages gratuitously." Helvering v. American Dental Co., 318 U.S. 322, 330 (1943). A gift must lack "the constraining force of any moral or legal duty as well as the incentive of anticipated benefit of any kind beyond the satisfaction which flows from the performance of a generous act." Bogardus v. Commissioner, 302 U.S. 34,41 (1937).
} 
strikers who are not union members, union members who have not paid dues, and union members who have paid dues. In the instant case, the taxpayer was not a union member for approximately half of the time that he received payments, and for the remainder of the time, he was a union member but did not pay dues. The case could thus be interpreted to have application to strike payments to both nonunion workers and to union members who have never paid dues. Difficulty might be encountered, however, if the reasoning of the Kaiser case were extended to a case involving a dues paying union member, since he would have given consideration for the strike benefits through payment of his union dues, which are deductible for income tax purposes. Thus, the Kaiser decision cannot answer what is probably the most important question in the area of taxability of strike benefits.

The case may also have significance in controversies involving lockout and unemployment benefits paid by a union, for in these situations, unlike a strike, it is difficult to point to a direct benefit accruing to the union as a result of the worker's inactivity. It would, therefore, be possible to find that such payments were motivated by sympathy for needy workers and accordingly should be treated as gifts. Such an argument would lose much of its force, however, if the taxpayer was eligible for lockout or unemployment benefits only if he regularly paid dues to the union.

Under the approach asserted in the Kaiser case, each strike benefit plan will have to be examined closely to determine whether it is actually based on need. The same close scrutiny must, presumably, be accorded cases involving lockout and unemployment benefits. Yet, it would seem a simple matter for any union to make its benefit payments in such a manner as to comply with this blueprint. Accordingly, the practical result of the case could well be to make all strike, lockout, and unemployment benefits nontaxable. The undesirability of such a result indicates the need for a reappraisal of the Kaiser decision. 